Article

\title{
Hay Yield and Water Use Efficiency of Alfalfa under Different Irrigation and Fungicide Regimes in a Semiarid Climate
}

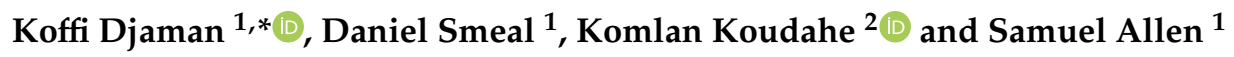 \\ 1 Agricultural Science Center at Farmington, Department of Plant and Environmental Sciences, \\ New Mexico State University, P.O. Box 1018, Farmington, NM 87499, USA; dsmeal@nmsu.edu (D.S.); \\ samallen@nmsu.edu (S.A.) \\ 2 Consultant at ADA Consulting Africa, Lomé 07 BP 14284, Togo; koudahe_komlan@yahoo.fr \\ * Correspondence: kdjaman@nmsu.edu; Tel.: +1-505-960-7757
}

Received: 3 May 2020; Accepted: 12 June 2020; Published: 16 June 2020

\begin{abstract}
Alfalfa is one of the most nutritive and high-yielding forage legumes planted in rotation with cereal crops across the United States. Under semiarid and arid climates with limited water resources, sustainable management of the available resources is required. The objective of this study was to investigate the effect of different irrigation regimes and fungicide applications on alfalfa in the high desert region of the Colorado Plateau of the U.S. Field experiments were conducted during the 2012-2014 period. Alfalfa was planted in fall 2012, uniformly irrigated for crop establishment and subjected to seven different irrigation regimes after the first cut in spring 2013. Alfalfa was treated by fungicide application and was harvested at $10 \%$ blooming. The maximum amounts of applied water were 350, 300, 208, and $312 \mathrm{~mm}$, respectively, during the first, second, third, and fourth regrowth cycles in 2013, and 373, 282, 198, and $246 \mathrm{~mm}$ in 2014 for the respective regrowth cycles in 2014; the seasonal applied irrigation amount varied from 711 to $1171 \mathrm{~mm}$ in 2013 and from 328 to $1100 \mathrm{~mm}$ in 2014. The results showed non-significant effect of fungicide application on the forage yield. Alfalfa forage yield was significantly affected by the irrigation regimes and showed a third order polynomial relationship with the applied irrigation amounts during each regrowth cycle and on seasonal scale. Forage yield decreased from the first cut to the fourth cut and the annual forage varied from 10.6 to $25.7 \mathrm{Mg} / \mathrm{ha}$ for the treated alfalfa and from 11.5 to $25.6 \mathrm{Mg} / \mathrm{ha}$ for the non-treated alfalfa. Forage yield at each cut accounted for 39.6, 24.2, 17.6, and 18.6\% of the 2013 season forage yield and $31.4,23.8,21.6$, and $23.2 \%$ of the 2014 season forage yield, for the first, second, third, and fourth cut, respectively. Alfalfa water use efficiency varied from 0.06 to $3.3 \mathrm{~kg} / \mathrm{m}^{3}$. The relationships developed in this study could be used by forage growers, crop consultants, and project managers for decision making and planning to improve the productivity of water under the semiarid and arid climate of New Mexico and the surrounding regions.
\end{abstract}

Keywords: alfalfa; irrigation; forage; water productivity; New Mexico

\section{Introduction}

Agricultural water is the most limiting factor for crop production in arid and semiarid environments, where actual crop evapotranspiration is not met by the received precipitation. Under such conditions, supplementary irrigation is necessary for crops to meet their water requirements for optimum food and fiber production [1]. Irrigation water requirements for alfalfa vary with climate and local precipitation patterns and amounts, and its yield depends on watering regimes and management. Linear increase of alfalfa yield with irrigation amount was reported by Rogers et al. [2] in Australia 
with yields ranging from 1.4 to $17.7 \mathrm{Mg} / \mathrm{ha}$. A similar relationship was found by Shewmaker et al. [3], Arshad et al. [4], and Lei et al. [5], who pointed out that drought tolerance in alfalfa is a key challenge in improving its productivity. Lindenmeyer et al. [6] reported an increase in alfalfa biomass yield as a function of seasonal evapotranspiration across the U.S. Great Plains with annual crop water use from 615 to $1448 \mathrm{~mm}$. Alfalfa has a relatively high irrigation water requirement and long growing season and the irrigated alfalfa represents $12 \%$ of the alfalfa-produced area in the U.S. [7,8]. Putnam et al. [9] suggested that deficit irrigation on alfalfa might help in achieving significant water savings. Undersander et al. [10] indicated that water stress is the most limiting factor for alfalfa production. Lindenmayer et al. [11] and Ismail and Almarshadi [12] indicated that alfalfa forage quality and water productivity were improved under deficit irrigation with yield reduction [13,14]. Li et al. [15] reported significant impact of irrigation regime on the alfalfa annual forage yield with significant differences between 100, 80, and 60\% evapotranspiration (ET) irrigation levels. They reported that the seasonal yields for each cutting were significantly affected by irrigation level, except for the third cutting with better precipitation received. The yield of the first cutting is a major determinant of forage annual yield [16,17]. The first cutting usually benefits from longer growth period with greater accumulated thermal units allowing greater biomass accumulation [15,17,18]. Li et al. [15] reported quadratic relationships between forage yield and the applied irrigation amount during the 1st, 2nd, and 3rd cuts. Yield reduction of alfalfa under deficit irrigation has been reported by other studies elsewhere [2,3,11-13,19-25]. Rogers et al. [2] reported the capacity of alfalfa to recover from drought. Under semiarid and arid conditions, alfalfa is mostly adapted to drought due to its deep rooting system [26-30]. Summers et al. [31] found that irrigated alfalfa represents more than $90 \%$ of the alfalfa acreage across the western states while rainfed alfalfa is produced in some western regions such as Montana. Li and Su [32] reported alfalfa annual forage yield as a function of irrigation amount and which varied from 11.7 to $18.6 \mathrm{Mg} / \mathrm{ha}$ in China with an increasing trend in seasonal irrigation [12,33]. Bolger and Matches [34] reported alfalfa first cut yield to be 41-46\% of the annual yield while Li and $\mathrm{Su}$ [32] indicated the first cut yield as $35-50 \%$ of the annual forage yield relative to irrigation rates. Cavero et al. [35] reported that the maximum alfalfa forage yield was lower in the first year $(17 \mathrm{Mg} / \mathrm{ha})$ than in the two following years (20-22 Mg/ha). Tesar and Marble [36] reported that optimum alfalfa plant populations varied from 140 to 260 plants $/ \mathrm{m}^{2}$ for maximum forage yield while Krueger et al. [37] and Kephart et al. [38] reported the relationships between stem diameter, shoot weight, and planting date. In most of the western U.S., alfalfa production depends on irrigation, while elsewhere in the U.S., alfalfa can be grown under rainfed conditions without any supplementary irrigation [39].

The water use efficiency (WUE) of alfalfa under sprinkler irrigation, defined as alfalfa dry biomass production per unit volume of water, varied from 1.90 to $2.7 \mathrm{~kg} / \mathrm{m}^{3}$ in China [15,32]. Kuslu et al. [40] reported alfalfa water productivity that varied from 0.9 to $1.5 \mathrm{~kg} / \mathrm{m}^{3}$ within the range of rainfed, deficit, and fully sprinkler irrigated alfalfa in Turkey. The timing of deficit irrigation on alfalfa has different impacts on the biomass production-Orloff and Hanson [41] found that alfalfa yield was reduced by imposing deficit irrigation after the first cutting by 1.5 to $5.4 \mathrm{Mg} / \mathrm{ha}$, while irrigation cutoff after the second cutting reduced yields by 0.8 to $3.3 \mathrm{Mg} / \mathrm{ha}$ in California.

Alfalfa is subjected to abiotic and biotic stresses that can induce considerable hay yield reduction. Environmental conditions cause the main abiotic stresses and diseases are caused by biotic stresses, namely nematodes, bacteria, viruses, and fungi [42]. Foliar diseases can cause defoliation, yield reduction, and quality deterioration. In particular, fungus-like Pseudopeziza medicaginis ([Lib.] Sacc.) is the agent of alfalfa common leaf spot, Peronospora trifoliorum (de Bary) causes downy mildew on alfalfa, and Phoma medicaginis (Malbr. \& Roum.) causes spring blackstem on alfalfa crop. Stagonospora meliloti (Lasch) Petr. and Stemphylium botryosun (Wallr.) cause spots on leaves and stems, and Colletotrichum trifolii (Bain. \& Essary) causes anthracnose [42]. Several studies have reported yield improvement with fungicide applications [43-46]. Samac et al. [46] used a broad-spectrum fungicide that reduced alfalfa defoliation in 10 out of 14 harvests. Fungicides have the potential to increase alfalfa forage yields during periods of high disease pressure when used with irrigation management practices that 
maximize yields. Considering the paradigm of high water requirements by alfalfa versus the sensitivity of fungal diseases to high soil moisture and high intercepted irrigation or rainfall water by the crop, the application of fungicide under limited irrigation might improve alfalfa hay yield, water use efficiency, and economic return for alfalfa producers.

Alfalfa is one of the worldwide-grown perennial forage crops with high yields and high nutritive value. Alfalfa is characterized by high protein content and is often preferred by livestock compared to grasses [47-49]. Alfalfa is considered a high-value cash crop as well as having value as a cover crop incorporated into cropping systems preceding maize, wheat, and barley, for example [50]. Alfalfa is mostly planted in fall and its stand and establishment throughout the winter and the spring during the first year play a key role in its production and yield capacity. Annual alfalfa hay production in the U.S. was greater than 49 million $\mathrm{Mg}$ with a harvested area greater than 6.7 million ha [8]. Alfalfa is the second-most important crop grown in New Mexico with total harvested area of 76,890 ha with a total production of $950,000 \mathrm{Mg}$ corresponding to a value of $\$ 171$ million in 2017 [8]. Alfalfa hay is the most important hay in New Mexico valued at \$198 per Mg while other hay was \$179 per Mg in 2017 [8]. Alfalfa average state yield is $11.2 \mathrm{Mg} / \mathrm{ha}$ and its average yield in San Juan county, New Mexico (NM), was $11.7 \mathrm{Mg} / \mathrm{ha}$ in 2017. Improving alfalfa forage yield will help crop growers and the dairy economy that depends on alfalfa hay across the state. Accordingly, this research aims to investigate the effect of different irrigation regimes and fungicide application on alfalfa in the high desert region of the Colorado Plateau of the U.S. Due to the limited water resources and the aridity of the climate across the study area against the high water requirements of alfalfa, deficit irrigation strategies might help in improving water management in disease-free alfalfa and optimizing alfalfa water use efficiency under fungicide application.

\section{Materials and Methods}

\subsection{Study Area}

This study was conducted at the New Mexico State University (NMSU) Agricultural Science Center at Farmington, NM $\left(36.69^{\circ}, 108.31^{\circ}\right.$, elev. $\left.1720 \mathrm{~m}\right)$ during the 2012-2014 period. The soil type at the study site is a Doak fine-loamy, mixed, active, mesic Typic Haplargid. Climatic variables such as minimum temperature (Tmin), maximum temperature (Tmax), average temperature (Tmean), solar radiation, wind speed, and precipitation were collected daily from an automated weather station installed at the study site.

\subsection{Crop Management}

A field previously planted to canola (Brassica napus L.) was prepared for alfalfa planting in May 2012. The field was disked and fertilized with $28 \mathrm{~kg} \mathrm{~N} \mathrm{ha}^{-1}$ and $133 \mathrm{~kg} \mathrm{P}_{2} \mathrm{O}_{5} \mathrm{ha}^{-1}$ on 17 May 2012. Fertilizer was broadcast and incorporated into the soil with spring tooth and spike tooth harrows prior to planting. Alfalfa (cv. Genuity ${ }^{\circledR}$ RR) seed was dropped onto the soil surface at an approximate rate of $24 \mathrm{~kg}$ seed $\mathrm{ha}^{-1}$ with a grain drill and then incorporated into the soil with a harrow on 17 May 2012. A roller was then used to lightly pack the soil to provide good seed-soil contact. The total planted area was $36.6 \mathrm{~m} \times 55 \mathrm{~m}$ (0.20 ha). A solid-set sprinkler irrigation system consisting of 98.5-m long sprinkler lines spaced $15.2 \mathrm{~m}$ apart was set up to irrigate the plot after planting and the first irrigation event at a depth of $38 \mathrm{~mm}$ was applied on 21 May 2012. Light irrigations at the rate of $5 \mathrm{~mm}$ were applied every two to three days through mid-June for seed germination and establishment. A mix of Raptor (420.3 $\left.\mathrm{g} \mathrm{ha}^{-1}\right)$, Roundup Weathermax (2241.7 $\left.\mathrm{g} \mathrm{ha}^{-1}\right)$, crop oil concentrate $\left(1120.9 \mathrm{~g} \mathrm{ha}^{-1}\right)$, and sprayable ammonium sulfate $\left(2.2 \mathrm{~g} \mathrm{ha}^{-1}\right)$ was sprayed on the alfalfa on 13 June 2012 for weed control (mainly pigweed, Russian thistle, and puncture vine). Irrigations were then applied twice per week at a depth of about $19 \mathrm{~mm} /$ irrigation throughout the rest of the growing season. A mix of Roundup (Powermax), ROC, and ammonium sulfate at rates of $1105.6 \mathrm{~g}, 249.5 \mathrm{~g}$, and $124.7 \mathrm{~g}$, respectively, was sprayed on 5 July 2012 to control primarily Russian thistle. Alfalfa was cut for the first time on 
6 August 2012. The final 2012 season irrigation was applied on 11 October. The 2012 season was an establishment year and no treatments were applied, and yield data were not collected.

The treatments (combination of fungicide and irrigation regimes) were applied in 2013 and 2014. Priaxor $^{\circledR}$ is a fungicide containing $14.3 \%$ fluxapyroxad and $28.6 \%$ pyraclostrobin that is registered for controlling various fungal diseases in a variety of crops. In 2013 , the alfalfa was irrigated uniformly during the first growing period (cut 1) to quantify relative damage to plot areas caused by pocket gophers (Geomys bursarius) prior to initiating irrigation or fungicide treatments. Gopher chasers (noise makers) and traps were used to help minimize further damage by the rodents during this first growth period. An initial, $50.4 \mathrm{~mm}$, irrigation was applied on April 8. Subsequent irrigations during cut 1 were applied about every six to seven days at depths equal to estimated alfalfa evapotranspiration (ET) since the previous irrigation. Beginning on 14 June (after the first harvest), irrigation treatments were applied using a sprinkler line-source (SLS) design [51]. The design consisted of a single $76.2 \mathrm{~mm}$ diameter sprinkler line with Rainbird ${ }^{\circledR} 30 \mathrm{H}$ sprinklers mounted on $1.2 \mathrm{~m}, 25.4 \mathrm{~mm}$ diameter risers spaced at 6-m intervals. The plot size was $1.5 \mathrm{~m} \times 12.2 \mathrm{~m}$. Seven irrigation regimes $(50,60,70,80,90,100$, and $110 \%$ of crop evapotranspiration (ETc) at full irrigation) were combined with two fungicide rates (treated and non-treated) and arranged in the complete blocks design with six replications. Daily alfalfa crop evapotranspiration for the full irrigation treatment was estimated as the product of the daily United Nations Food and Agriculture Organization (FAO) Penman-Monteith reference evapotranspiration $(E T o)$ by alfalfa crop coefficients, $\mathrm{kc}(\mathrm{ETC}=\mathrm{kc}$ ETo). Daily FAO Penman-Monteith ETo values were estimated using the climate variables measured and monitored on site by an automated weather station. Irrigation event dates were the same for all irrigation treatments in 2013 and 2014. A backpack sprayer was used to apply Headline broad-spectrum fungicide at a rate of $420.3 \mathrm{~g} \mathrm{ha}^{-1}$ to the treated plots when alfalfa reached $15.2 \mathrm{~cm}$ in height after the cuts 1,2, and 3. Alfalfa forage was harvested four times during 2013 and 2014 at approximately 10\% bloom stage using an Almaco forage harvester equipped with a weigh bin and scales. Alfalfa dry weight per plot was determined after oven drying at $55^{\circ} \mathrm{C}$ until constant weight. Forage yield was reported at a calculated moisture percent of $20 \%$. Irrigation water use efficiency was estimated by the ratio of the forage yield to the applied irrigation amount.

\subsection{Statistical Analysis}

The analysis of variance (ANOVA) was performed to analyze alfalfa forage yield and irrigation water efficiency per cutting and growing season using CoStat statistical software. The data were checked for variance homogeneity before the ANOVA processing. Means were cross-paired and compared using LSD at 5\% significance level. Significant differences were determined among irrigation regimes for forage yield using the analysis of variance and the least significant difference (LSD). Regression analysis was also performed to develop the relationships between alfalfa forage yield and the irrigation amounts during each regrowth cycle and the growing season. Similar relationships were developed between alfalfa water use efficiency and the irrigation amounts. The coefficient of determination $\mathrm{R}^{2}$ was used to quantify the fitness of the relationships.

\section{Results and Discussion}

\subsection{Air Temperature and Precipitation Conditions during the 2012-2014 Period}

Daily average temperature varied from -10.3 to $29.2^{\circ} \mathrm{C}$ in 2012 , from -13.1 to $28.6^{\circ} \mathrm{C}$ in 2013 , and from -9.7 to $28.3^{\circ} \mathrm{C}$ in 2014 . Annual average temperature was $12.6,11.2$, and $12.1^{\circ} \mathrm{C}$ in 2012 , 2013 , and 2014, respectively (Figure 1). The highest average daily temperature was reached on 22 June in 2012, 13 July in 2013, and 22 July in 2014. The lowest temperature was reached on 20 December in 2012, 15 January 2013, and 26 December 2014. With the base temperature of $5{ }^{\circ} \mathrm{C}$ [18], the thermal units available for alfalfa production were 3189,2992 , and $2989^{\circ} \mathrm{C}$ in 2012,2013 , and 2014, respectively. With alfalfa thermal requirements of $585{ }^{\circ} \mathrm{C}$ for the first alfalfa cut and $425{ }^{\circ} \mathrm{C}$ for the subsequent cuts (1860 ${ }^{\circ} \mathrm{C}$ for four cuts), alfalfa should theoretically be cut four times during each year and regrow 
significantly after the fourth cut before winterizing. Total annual precipitation was $121.4,228.8$, and $167.9 \mathrm{~mm}$ in 2012, 2013, and 2014, respectively, and the received precipitation amount during alfalfa growing season (March to October) was 67.3, 172.2, and $104.9 \mathrm{~mm}$ in 2012, 2013, and 2014, respectively (Figure 1). The limited amount of precipitation during alfalfa growing period calls for irrigation demand under the semiarid climate in northwest New Mexico [52].
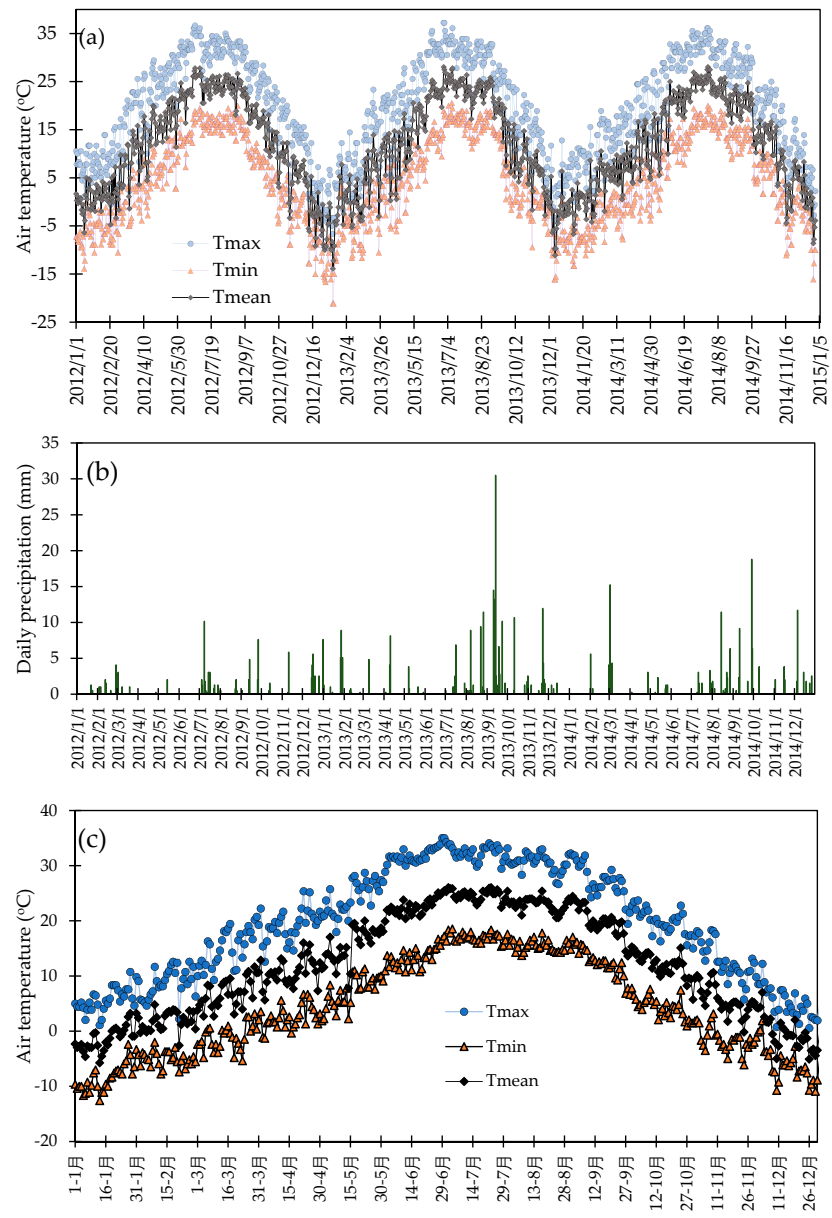

Figure 1. Evolution of the (a) daily maximum (Tmax), minimum (Tmin), and mean (Tmean) air temperatures, (b) precipitation during the 2012-2014 period, and (c) the 2012-2014 average daily maximum, minimum, and mean air temperatures, and daily precipitation.

\subsection{Alfalfa Response to Irrigation Regimes during Each Crop Regrowth Cycle and Crop Growing Season}

During the 2013 and 2014 growing seasons, alfalfa forage yield showed a third order polynomial relationship with the applied irrigation amount with the coefficient of correlation greater than 0.93 during each regrowth cycle (Figures 2 and 3). Fungicide application showed non-significant effect on forage yield in 2013 and 2014 (Table 1; $p=0.6307$ ). Forage yield at the first cut in 2013 was similar for all treatments as the same irrigation amount was applied to all treatments for better crop establishment. The maximum amount of applied water was 350, 300, 208, and $312 \mathrm{~mm}$ during the first, second, third, and fourth regrowth cycles in 2013, respectively (Figure 2). The greatest total irrigation amounts applied in 2014 were 374, 282, 198, and $246 \mathrm{~mm}$ for the respective regrowth cycles. Alfalfa forage yield significantly decreased from the first cut to the fourth cut. Maximum forage yield of $7.5 \mathrm{Mg} / \mathrm{ha}$ was obtained under the irrigation amount of $279.4 \mathrm{~mm}$ and yield decreased at high irrigation amount during the second cut in 2013 while forage yield plateaued at irrigation amount of 190.5 and $208.3 \mathrm{~mm}$ during the third regrowth period. During the fourth regrowth period, forage yield increased with the applied irrigation. The maximum yield was obtained at $241.3 \mathrm{~mm}$ and the yield decreased significantly 
thereafter with increasing irrigation amount (Table 1) (Figure 2). Forage yield averaged 7.8, 4.6, 3.4, and $3.9 \mathrm{Mg} / \mathrm{ha}$ for the treated alfalfa and $8.1,5.0,3.6$, and $3.5 \mathrm{Mg} / \mathrm{ha}$ for the untreated alfalfa for the first, second, third, and fourth cuts in 2013, respectively. The maximum applied irrigation amounts were $373.4,282,198$, and $246.4 \mathrm{~mm}$ during the first, second, third, and fourth regrowth cycles, respectively, in 2014. The highest forage yield was obtained under the highest irrigation except for the last regrowth cycle where the maximum forage yield was obtained at the applied irrigation amount of $193 \mathrm{~mm}$. The maximum forage yield was 9.0,6.6, 5.7, and 4.5 Mg/ha under fungicide treatment and 8.6, 6.6, 5.9, and $4.5 \mathrm{Mg} /$ ha under non-fungicide treatment during the first, second, third, and fourth cuts in 2014, respectively. These results are in contrast to Nutter et al. [44] who reported significant forage yield loss of 19.2\% due to fungal diseases across Iowa, Ohio, Vermont, and Wisconsin from 1995 to 1998. Alfalfa forage yield increase of 7.4\% was associated with the fungicide Mancozeb in Kansas [53] while in Arizona, Matheron and Matejka [54] reported alfalfa yield increased within the range of 7.5-13.0\% with chlorothalonil application. The difference in the research results might have been influenced by the difference in the climatic conditions between the humid region and semiarid to arid region of northwest New Mexico. While fungal diseases are present in the study area, based on classic climatic comparisons, the emergence and severity of the pressure and impact of these diseases in a semiarid area are non-significant and sometimes completely unexpected [55-58]. In fact, the low relative humidity and high air temperature are non-favorable conditions for the development and spread of the fungal diseases in the desert area.

Alfalfa total annual forage also showed a third order polynomial relationship with the seasonal irrigation amount in the 2013 and 2014 (Figure 4). Seasonal applied irrigation amount varied from 711 to $1171 \mathrm{~mm}$ in 2013 and from 328 to $1100 \mathrm{~mm}$ in 2014. The lower limit of applied irrigation amount in 2013 was greater than the lower limit in 2014 due to uniform irrigation amount application during the first regrowth period in 2013 for better crop establishment. Similar to each regrowth cycle, there was no significant difference between the treated and untreated alfalfa forage yields (Table $1 ; p \geq 0.05$ ). Annual forage varied from 10.6 to $25.7 \mathrm{Mg} / \mathrm{ha}$ for the treated alfalfa and from 11.5 to $25.6 \mathrm{Mg} / \mathrm{ha}$ for the untreated alfalfa in 2013 while it varied from 4 to $25.8 \mathrm{Mg} /$ ha for the treated alfalfa and from 2.9 to $25.6 \mathrm{Mg} / \mathrm{ha}$ for the untreated alfalfa during the 2014 crop growing season. In 2013, seasonal forage yield significantly increased with irrigation amount up to $1112.5 \mathrm{~mm}$ and decreased at the seasonal applied irrigation amount of $1171 \mathrm{~mm}$. In 2014, alfalfa seasonal forage yield also increased significantly with the applied irrigation amount and the applied irrigation amount of 1003.3 and $1100 \mathrm{~mm}$ obtained non-significantly different yields (Figure 4). The 2013 and 2014 data pooled together showed a significantly increasing trend in alfalfa forage yield with the applied irrigation amount and the yield plateaued with $24.5 \mathrm{Mg} /$ ha at the applied irrigation rate of $1031 \mathrm{~mm}$ and thereafter. The curve of developed alfalfa response to irrigation could be used by alfalfa hay producers for decision making with regard to the seasonal available water for planning and in-season water management.

The first, second, third, and fourth cut accounted for 39.6, 24.2, 17.6, and 18.6\% of the 2013 season forage yield and $31.4,23.8,21.6$, and $23.2 \%$ of the 2014 season forage yield, respectively. These results are in agreement with Djaman et al. [17] who found alfalfa forage yield decreased from the cut 1 to the cut 4 , which represented on average 33, 29, 22, and 16\% of the annual yield that varied from 15.5 to $29.9 \mathrm{Mg} / \mathrm{ha}$. $\mathrm{Li}$ and $\mathrm{Su}$ [32] reported increasing forage yield of alfalfa with irrigation and it varied from 11.6 to $18.6 \mathrm{Mg} / \mathrm{ha}$ in the desert climate of north China. However, the forage yield reported in this study is higher than the reported yields by $\mathrm{Li}$ and $\mathrm{Su}$ [32]. Bolger and Matches [34] found that the first cut of alfalfa represented about $41-46 \%$ of the seasonal yield. Hanson et al. [20] reported a curvilinear relationship between alfalfa forage yield and the applied irrigation amount in the arid region of the southern U.S. However, they pointed out that this relationship varied with the regrowth cycles as the stored soil moisture and the early spring precipitation may be sufficient for alfalfa growth during the first regrowth cycle. The decrease in alfalfa forage yield after a certain amount of irrigation is applied indicated irrigation exceeding maximum crop evapotranspiration as noticed during the second and fourth regrowth cycles in 2013 and the fourth regrowth cycle in 2014. 
A third order polynomial relationship in eastern China was reported by Yang et al. [59]. A linear relationship was reported between alfalfa forage yield and applied irrigation amount in the northern desert zone of China [32]. A similar relationship was reported by Sammis [60] and Shewmaker et al. [3]. A quadratic relationship was reported by Montazar and Sadeghi [61] while Klocke et al. [62] reported nearly a linear relationship between alfalfa forage yield and the applied irrigation amount during from the second to the fourth year of production and a linear relationship during the fifth year of alfalfa production. Different relationships were reported between alfalfa forage yield and irrigation amounts during different alfalfa regrowth cycles [34]. The precipitation distribution and magnitude at the site might have impacted these relationships as, similarly to the present research location case, irrigation is more critical under semiarid and arid climates. Alfalfa forage yield response to the applied irrigation amount should be looked at closely as it may vary from year to year and be impacted by the seasonal precipitation, the stored soil moisture, other biotic and abiotic stresses, and other environmental conditions.
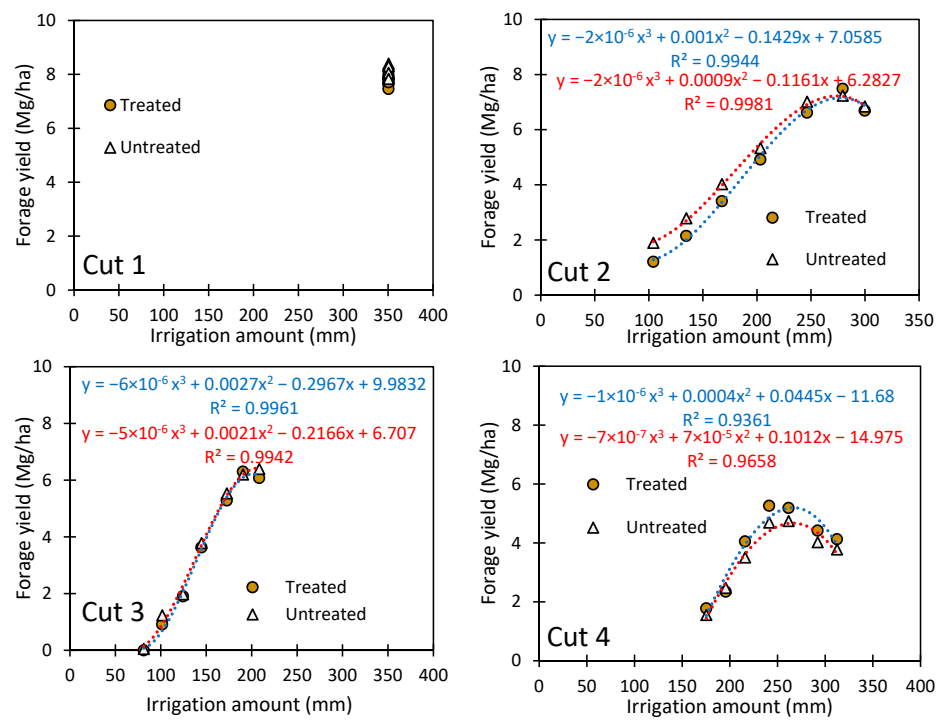

Figure 2. Forage yield as a function of irrigation amount at each cut during the 2013 growing season.
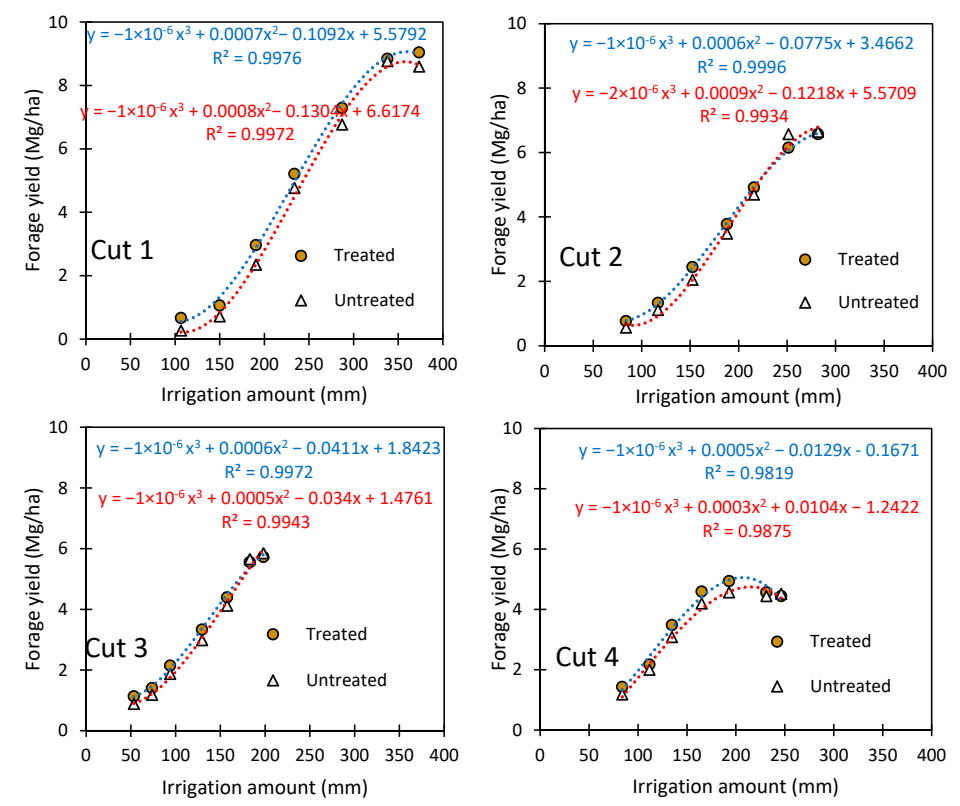

Figure 3. Forage yield as a function of irrigation amount at each cut during the 2014 growing season. 

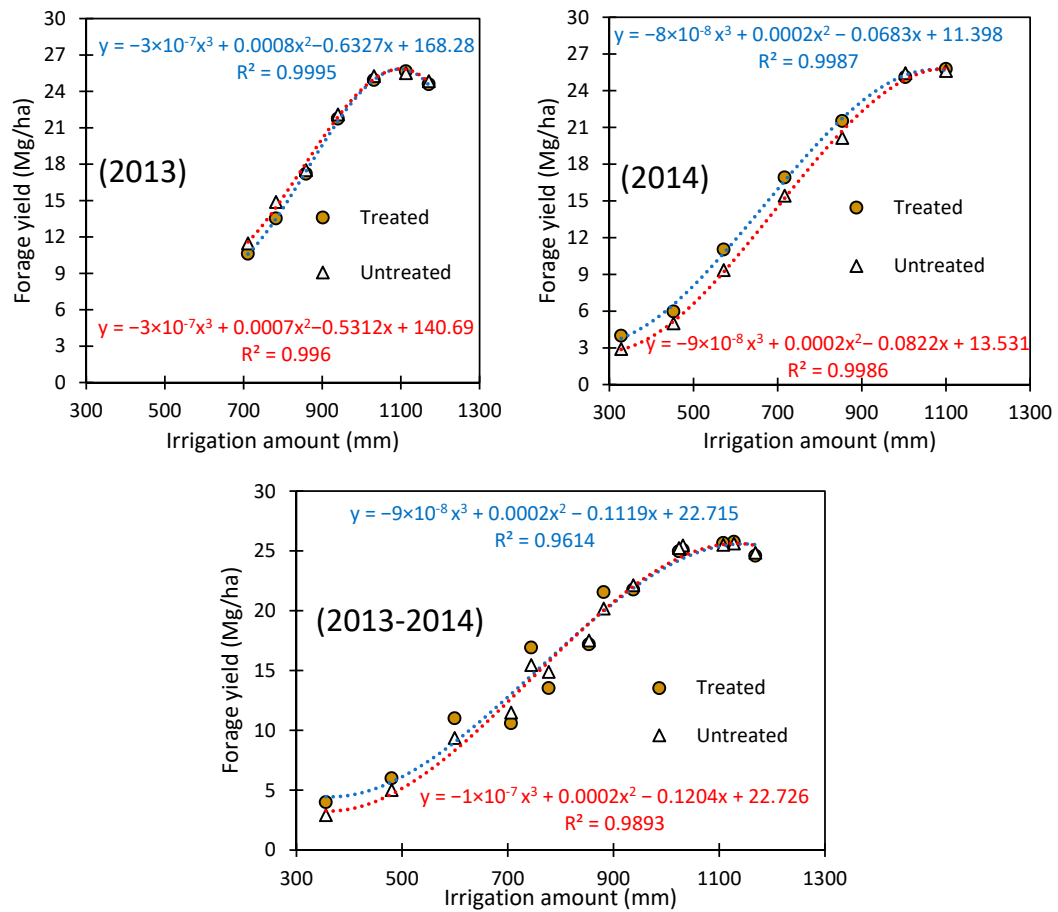

Figure 4. Annual forage yield as a function of irrigation amount in the 2013 and 2014 growing seasons and on average for 2013-2014.

Table 1. Summary of the analysis of variance (ANOVA) of the 2012-2014 alfalfa experiment.

\begin{tabular}{ccccccc}
\hline Source & df & Type III SS & MS & F & $\boldsymbol{P}$ & Significance \\
\hline Blocks & 5 & 61.83997802 & 12.36799 & 5.721 & 0.000 & $* * * *$ \\
Main effects & & & & & & \\
Irrigation & 6 & 1991.41806 & 331.9030 & 153.53 & 0.000 & $* * *$ \\
Fungicide & 1 & 0.500182573 & 0.500183 & 0.231 & 0.631 & ns \\
$\quad$ Cut & 3 & 919.469364 & 306.48979 & 141.77 & 0.0000 & $* * *$ \\
Interactions & & & & & & \\
Irrigation $\times$ fungicide & 6 & 1.175629246 & 0.1959382 & 0.090 & 0.997 & ns \\
$\quad$ Irrigation $\times$ cut & 18 & 190.3570301 & 10.575391 & 4.891 & 0.0000 & $* * *$ \\
$\quad$ Fungicide $\times$ cut & 3 & 3.903725634 & 1.3012419 & 0.602 & 0.6139 & ns \\
Irrigation $\times$ fungicide $\times$ cut & 18 & 1.516643377 & 0.084258 & 0.039 & 1 & ns \\
Error & 611 & 1320.86208 & 2.1618037 & & & \\
Total & 671 & 4491.042693 & & & & $*$ \\
Model & 60 & 3170.180612 & 52.836344 & 24.440 & 0.000 & $* * *$ \\
\hline
\end{tabular}

$\mathrm{df}=$ degree of freedom, $\mathrm{SS}=$ sum squares, $\mathrm{MS}=$ mean squares, $\mathrm{F}=$ the test statistic, $P=p$-value, Significance: $\mathrm{ns}=$ non-significant; ${ }^{* * *}=$ significant at $p$ value $=0.001$.

3.3. Alfalfa Water Use Efficiency as a Function of Applied Irrigation Amount during Each Crop Regrowth Cycle and Crop Growing Season

Alfalfa water use efficiency varied with the applied irrigation amount and regrowth cycle with non-significant higher water use efficiency under fungicide application in 2014. It ranged from 2.2 to $2.3 \mathrm{~kg} / \mathrm{m}^{3}, 1.16$ to $2.85 \mathrm{~kg} / \mathrm{m}^{3}, 0.06$ to $3.3 \mathrm{~kg} / \mathrm{m}^{3}$, and 0.9 to $2.2 \mathrm{~kg} / \mathrm{m}^{3}$ for the first, second, third, and fourth cuts in 2013 (Figure 5) and from 0.20 to $2.6 \mathrm{~kg} / \mathrm{m}^{3}, 0.7$ to $2.6 \mathrm{~kg} / \mathrm{m}^{3}, 1.6$ to $3.1 \mathrm{~kg} / \mathrm{m}^{3}$, and 1.4 to $2.8 \mathrm{~kg} / \mathrm{m}^{3}$, for the respective regrowth cycles in 2014 (Figure 6). Except for the first regrowth cycle in 2013, with uniform applied irrigation amount, the maximum alfalfa water use efficiency was obtained with $246.8,190.5$, and $241.3 \mathrm{~mm}$ of applied water for the second, third, and fourth regrowth cycles in 2013 and 337.8, 251.5, 182.8, and $165.1 \mathrm{~mm}$ for the respective regrowth cycles in 2014. The optimum irrigation amounts with the maximum water use efficiency are lower than the applied irrigation amounts coinciding with the maximum forage yield during each regrowth cycle and should be considered for sustainable forage production system under limited water resources in the arid and semiarid climate of northwest New Mexico and the regions with similar climate and crop management practices. On a seasonal basis, alfalfa water use efficiency increased from $1.5 \mathrm{~kg} / \mathrm{m}^{3}$ to $2.5 \mathrm{~kg} / \mathrm{m}^{3}$ at the 
applied irrigation amount of $1031.2 \mathrm{~mm}$ and decreased thereafter with increased irrigation amount in 2013 while it increased from $0.8 \mathrm{~kg} / \mathrm{m}^{3}$ to $2.5 \mathrm{~kg} / \mathrm{m}^{3}$ under applied irrigation amount of $853.4 \mathrm{~mm}$ and decreased with higher applied irrigation water (Figure 7). The water use efficiency values observed in this study are in agreement with Yang et al. [59] who reported water use efficiency values that ranged from 1.3 to $2.5 \mathrm{~kg} / \mathrm{m}^{3}$ under desert climate in China. Li and Su [32] reported alfalfa water use efficiency within the range of $2.3-2.7 \mathrm{~kg} / \mathrm{m}^{3}$ in northwest China. Lamm et al. [63] indicated large variation in alfalfa response to the applied irrigation water due to the deep rooting system of the crop that allows extraction of soil water in the deep soil layer under limited water supply [64].
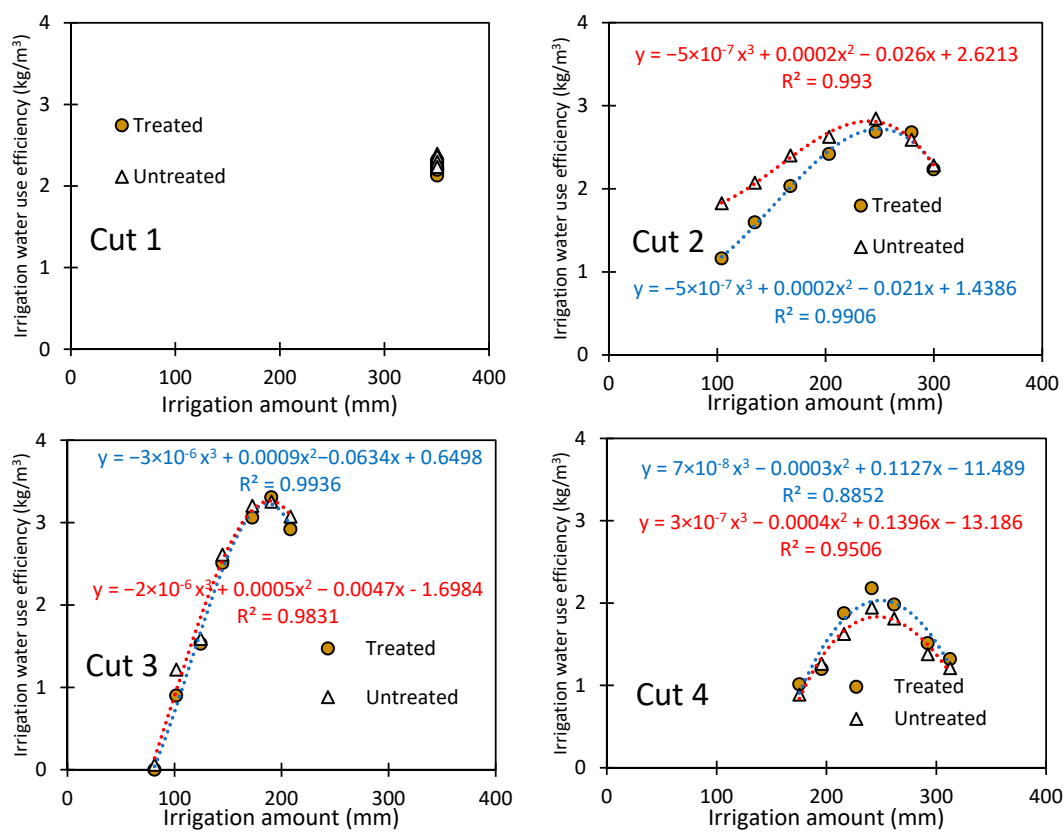

Figure 5. Irrigation water use efficiency of alfalfa as function of irrigation amount at each cut during the 2013 growing season.
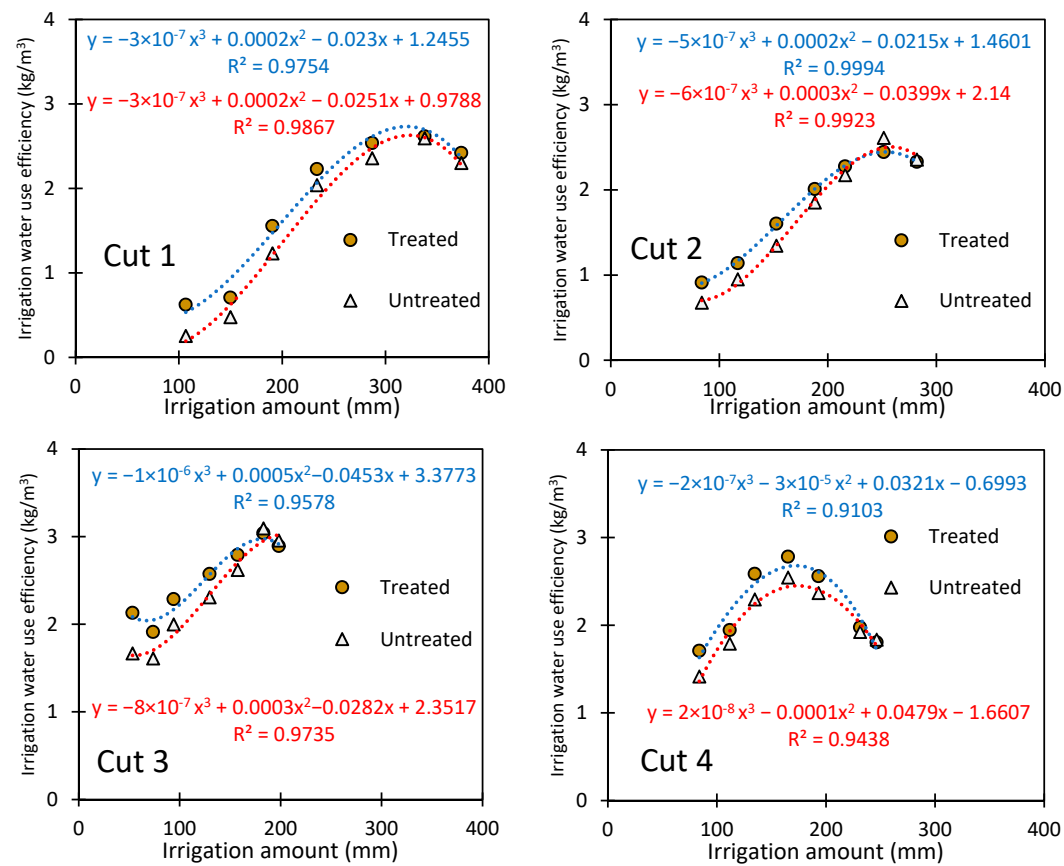

Figure 6. Irrigation water use efficiency of alfalfa as function of irrigation amount at each cut during the 2014 growing season. 

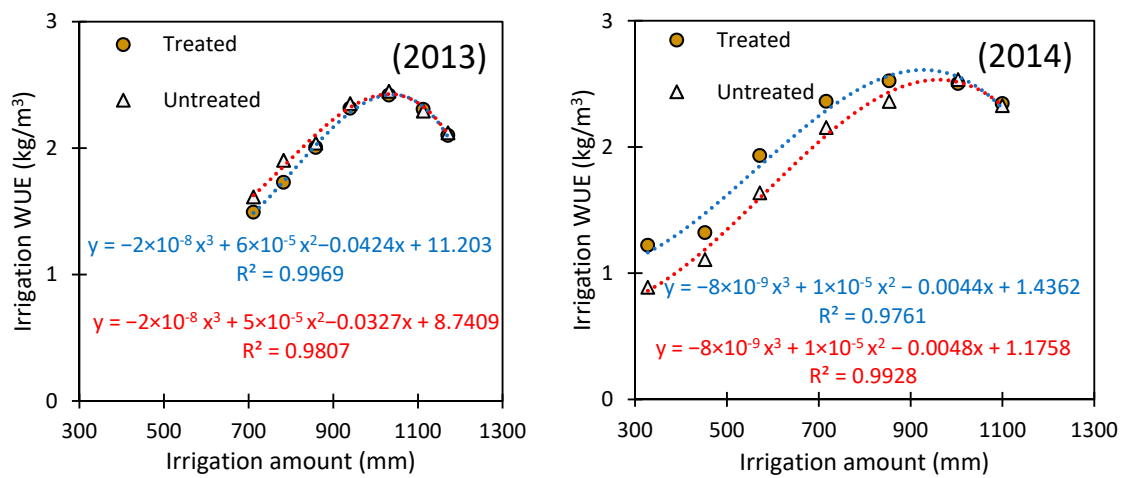

Figure 7. Irrigation water use efficiency of alfalfa as function of irrigation amount in 2013 and 2014 growing seasons.

\section{Conclusions}

This study evaluated alfalfa response to irrigation under fungicide and non-fungicide application during the 2012-2014 period. Alfalfa forage yield showed a curvilinear relationship with the applied irrigation amount during each of the four regrowth cycles in 2013 and 2014 and at seasonal scale. The fourth regrowth cycle required less water than the first three regrowth cycles and forage yield decreased from the first to the fourth cut. Fungicide application had no significant effect on alfalfa forage yield. There was a "significant" difference in alfalfa water use efficiency among cuts. At seasonal scale, the highest alfalfa water use efficiency value of $2.5 \mathrm{~kg} / \mathrm{m}^{3}$ was obtained with $1031.2 \mathrm{~mm}$ and $853.4 \mathrm{~mm}$ of applied irrigation water in 2013 and 2014, respectively, which corresponded to $90 \%$ of alfalfa irrigation requirements. This treatment allows a $10 \%$ savings in irrigation water that could be used to expand production or be reported to the following seasons under the semiarid and arid conditions of the study area. However, the interannual variability in the weather conditions in the study area may impact the optimum applied irrigation amount. The results of this study may help forage growers, consultants, and project managers improve project design and water resource planning and management under the unpredictable semiarid climate in New Mexico and neighboring regions.

Author Contributions: Conceptualization, D.S.; methodology, D.S.; software, K.D.; validation, D.S., K.D., and K.K.; formal analysis, K.D.; investigation, D.S.; resources, D.S.; data curation, K.K.; writing-original draft preparation, K.D.; writing-review and editing, K.D., K.K., and S.A. All authors have read and agreed to the published version of the manuscript.

Acknowledgments: We completed this work with the support of New Mexico State University (NMSU) and the Agricultural Science Center at Farmington and all the staff.

Conflicts of Interest: The authors declare no conflict of interest.

\section{References}

1. Djaman, K.; Irmak, S.; Rathje, W.R.; Martin, D.L.; Eisenhauer, D.E. Maize evapotranspiration, yield production function, biomass, grain yield, harvest index, and yield response factors under full and limited irrigation. Trans. ASABE 2013, 56, 273-293. [CrossRef]

2. Rogers, M.E.; Lawson, A.R.; Kelly, K.B. Lucerne yield, water productivity and persistence under variable and restricted irrigation strategies. Crop Pasture Sci. 2016, 67, 563-573. [CrossRef]

3. Shewmaker, G.E.; Allen, R.G.; Neibling, W.H. Alfalfa Irrigation and Drought; University of Idaho College of Agriculture and Life Science: Moscow, ID, USA, 2013; Available online: https://www.uidaho.edu/ \{\}/media/ UIdaho-Responsive/Files/Extension/Drought/Alfalfa-Irrigation-Facts.ashx (accessed on 15 February 2020).

4. Arshad, M.; Feyissa, B.A.; Amyot, L.; Aung, B.; Hannoufa, A. MicroRNA156 improves drought stress tolerance in alfalfa (Medicago sativa) by silencing SPL13. Plant Sci. 2017, 258, 122-136. [CrossRef] [PubMed]

5. Lei, Y.; Hannoufa, A.; Yu, P. The use and gene modification and advanced molecular structure analyses towards improving alfalfa forage. Int. J. Mol. Sci. 2017, 18, 298. [CrossRef] 
6. Lindenmayer, R.B.; Hansen, N.C.; Brummer, J.; Pritchett, J.G. Deficit irrigation of alfalfa for water savings in the Great Plains and Intermountain West: A review and analysis of the literature. Agron. J. 2011, 103, 45-50. [CrossRef]

7. Broner, I.; Schneekloth, J. Seasonal Water Needs and Opportunities for Limited Irrigation for Colorado Crops, Newsletter of the Extension Irrigation Services; No. 4.718; Department of Civil Engineering, Colorado State University: Fort Collins, CO, USA, 2013.

8. USDA (United States Department of Agriculture). New Mexico Agricultural Statistics 2016 Annual Bulletin; USDA: Las Cruces, NM, USA, 2018.

9. Putnam, D.; Orlaff, S.; Hanson, B.; Carlson, H. Con-trolled deficit irrigation of alfalfa in differing environments. In Abstracts 2005 International Annual Meetings, American Society of Agronomy, Crop Science Society of America, Soil Science Society of America, Salt Lake City, UT, USA, 6-10 November 2005; ASA; CSSA; SSSA: Madison, WI, USA, 2005.

10. Undersander, D.; Cosgrove, D.; Cullen, E.; Grau, C.; Rice, M.; Renz, M. Alfalfa Management Guide. American Society of Agronomy, Inc. 2011. Available online: https://www.agronomy.org/files/publications/ alfalfa-management-guide.pdf (accessed on 12 December 2019).

11. Lindenmayer, B.; Hansen, N.; Crookston, M.; Brummer, J.; Jha, A. Strategies for reducing alfalfa consumptive water use. In Proc. Hydrology Days; Colorado State University: Fort Collins, CO, USA, 2008; pp. 52-61.

12. Ismail, S.M.; Almarshadi, M.H. Maximizing productivity and water use efficiency of alfalfa under precise subsurface drip irrigation in arid regions. Irrig. Drain. 2013, 62, 57-66. [CrossRef]

13. Bauder, J.W.; Bauer, A.; Ramirez, J.M.; Cassel, D.K. Alfalfa water use and production on dryland and irrigated sandy loam. Agron. J. 1978, 70, 95-99. [CrossRef]

14. Cabot, P.; Brummer, J.; Gautam, S.; Jones, L.; Hansen, N. Benefits and Impacts of Partial Season Irrigation on Alfalfa Production. In Proceedings of the 2017 Western Alfalfa \& Forage Symposium, Reno, NV, USA, 28-30 November 2017.

15. Li, M.; Liu, Y.; Yan, H.; Sui, R. Effects of irrigation amount on alfalfa yield and quality with a center-pivot system. Trans. ASABE 2017, 60, 1633-1644. [CrossRef]

16. Lamb, J.F.; Jung, H.J.G.; Riday, H. Growth environment, harvest management, and germplasm impacts on potential ethanol and crude protein yield in alfalfa. Biomass Bioenergy 2014, 63, 114-125. [CrossRef]

17. Djaman, K.; Owen, C.; Koudahe, K.; O'Neill, M. Evaluation of Different Fall Dormancy-Rating Alfalfa Cultivars for Forage Yield in a Semiarid Environment. Agronomy 2020, 10, 146. [CrossRef]

18. Sharratt, B.S.; Sheaffer, C.C.; Baker, D. Base temperature for the application of the growing-degree-day model to field-grown alfalfa. Field Crop. Res. 1989, 21, 95-102. [CrossRef]

19. Saeed, I.A.M.; El-Nadi, A.H. Irrigation effects on the growth, yield, and water use efficiency of alfalfa. Irrig. Sci. 1997, 17, 63-68. [CrossRef]

20. Hanson, B.R.; Bali, K.M.; Sanden, B.L. Irrigating alfalfa in arid regions. In Irrigated Alfalfa Management in Mediterranean and Desert Zones; Summers, C.G., Putnam, D.H., Eds.; University of California Agriculture and Natural Resources Publication 8293; UCANR Publications: Oakland, CA, USA, 2017; Chapter 16; Available online: http://alfalfa.ucdavis.edu/IrrigatedAlfalfa (accessed on 21 January 2020).

21. Al-Naeem, M.A. Influence of Water Stress on Water Use Efficiency and Dry-Hay Production of Alfalfa in Al-Ahsa, Saudi Arabia. Int. J. Soil Sci. 2008, 3, 119-126. [CrossRef]

22. Slama, I.; Tayachi, S.; Jdey, A.; Rouached, A.; Abdelly, C. Differential response to water deficit stress in alfalfa (Medicago sativa) cultivars: Growth, water relations, osmolyte accumulation and lipid peroxidation. Afr. J. Biotechnol. 2011, 10, 16250-16259.

23. Holman, J.; Min, D.H.; Klocke, N.; Kisekka, I.; Currie, R. Effects of irrigation amount and timing on alfalfa nutritive value. Trans. ASABE 2016, 59, 849-860. [CrossRef]

24. Undersander, D. 2016 Alfalfa Trial Results. 2016. Available online: http://fyi.uwex.edu/forage/alfalfa-trialresults-2016/ (accessed on 5 April 2017).

25. Sakpota, A. Effect of Boron on Alfalfa Yield and Quality at Various Water Regimes. Master's Thesis, Montana State University, Bozeman, MT, USA, 2018; p. 144.

26. Moran, J.F.; Becana, M.; Iturbe-Ormaetxe, I.; Frechilla, S.; Klucas, R.V.; Aparicio-Tejo, P. Drought induces oxidative stress in pea plants. Planta 1994, 194, 346-352. [CrossRef] 
27. Erice, G.; Louahlia, S.; Irigoyen, J.J.; Sanchez-Diaz, M.; Avice, J.C. Biomass partitioning, morphology and water status of four alfalfa genotypes submitted to progressive drought and subsequent recovery. J. Plant Physiol. 2010, 167, 114-120. [CrossRef] [PubMed]

28. Kang, Y.; Han, Y.; Torres-Jerez, I.; Wang, M.; Tang, Y.; Monteros, M. System responses to long-term drought and re-watering of two contrasting alfalfa varieties. Plant J. 2011, 68, 871-889. [CrossRef] [PubMed]

29. Castroluna, A.; Ruiz, O.M.; Quiroga, A.M. Effects of salinity and drought stress on germination, biomass and growth in three varieties of Medicago sativa L. Av. Investig. Agropec. 2014, 18, 39-50.

30. Allen, R.G.; Pereira, L.S.; Raes, D.; Smith, M. Crop Evapotranspiration Guidelines for Computing Crop Water Requirements; FAO Irrigation and Drainage Paper 56; FAO: Rome, Italy, 1998.

31. Summers, C.; Putnam, D.; Bali, K.; Canevari, M.; Cangiano, C.; Castillo, A.; Godfrey, L. Irrigated Alfalfa Management for Mediterranean and Desert Zones; ANR University of California: Davis, CA, USA, 2008.

32. Li, Y.; Su, D. Alfalfa Water Use and Yield under Different Sprinkler Irrigation Regimes in North Arid Regions of China. Sustainability 2017, 9, 1380.

33. Li, X.; Wei, Y.; Acharya, A.; Hansen, J.L.; Crawford, J.L.; Viands, D.R.; Michaud, R.; Claessens, A.; Brummer, E.C. Genomic prediction of biomass yield in two selection cycles of a tetraploid alfalfa breeding population. Plant Genome 2015, 8, 90. [CrossRef]

34. Bolger, T.P.; Matches, A.G. Water-use efficiency and yield of sainfoin and alfalfa. Crop Sci. 1990, 30, $143-148$. [CrossRef]

35. Cavero, J.; Faci, M.; Medina, E.T.; Martínez-Cob, A. Alfalfa forage production under solid-set sprinkler irrigation in a semiarid climate. Agric. Water Manag. 2017, 191, 184-192. [CrossRef]

36. Tesar, M.B.; Marble, V.L. Alfalfa establishment. In Alfalfa and Alfalfa Improvement; Agron. Monogr. 29; Hanson, A.A., Barnes, D.K., Hill, R.R., Heichel, G.H., Hunt, O.J., Leath, K.T., Marten, G.C., Tesar, M.B., Eds.; ASA; CSSA; SSSA: Madison, WI, USA, 1988; pp. 303-332.

37. Krueger, W.C.; Laycock, W.A.; Price, D.A. Relationships of taste, smell, sight, and touch to forage selection. J. Range Manag. 1974, 27, 258-262. [CrossRef]

38. Kephart, K.D.; Twidwell, E.K.; Bortnem, R.; Boe, A. Alfalfa yield component responses to seeding rate several years after establishment. Agron. J. 1992, 84, 827-831. [CrossRef]

39. Mubako, S.T.; Lant, C.L. Agricultural virtual water trade and water footprint of U.S. states. Ann. Assoc. Am. Geogr. 2013, 103, 385-396. [CrossRef]

40. Kuslu, Y.; Shahin, U.; Tunc, T.; Kiziloglu, F.M. Determining Water-Yield Relationship, Water Use Efficiency, Seasonal Crop and Pan Coefficient for Alfalfa in a Semiarid Region with High Altitude. Bulg. J. Agric. Sci. 2010, 16, 482-492.

41. Orloff, S.; Hanson, B. Conserving water through deficit irrigation of alfalfa in the intermountain area of California. Forage Grazinglands 2008. [CrossRef]

42. Frate, C.A.; Davis, R.M. Alfalfa diseases and management. In Irrigated Alfalfa Management for Mediterranean and Desert Zones; Summers, C.G., Putnam, D.H., Eds.; University of California Agriculture and Natural Resources Publication 8296; UCANR Publications: Oakland, CA, USA, 2007; Chapter 10; Available online: http://alfalfa.ucdavis.edu/IrrigatedAlfalfa (accessed on 22 December 2019).

43. Campbell, C.L.; Duthie, J.A. Impact of leaf spot diseases on yield and quality of alfalfa in North Carolina. Plant Dis. 1990, 74, 241-245. [CrossRef]

44. Nutter, F.W.; Guan, J.; Gotlieb, A.R.; Rhodes, L.H.; Grau, C.R.; Sulc, R.M. Quantifying alfalfa yield losses caused by foliar diseases in Iowa, Ohio, Wisconsin, and Vermont. Plant Dis. 2002, 86, 269-277. [CrossRef]

45. Guan, J.; Nutter, F.W. Relationships between percentage defoliation, dry weight, percentage reflectance, leaf-to-stem ratio, and green leaf area index in the alfalfa leaf spot pathosystem. Crop Sci. 2002, 42, 1264-1273. [CrossRef]

46. Samac, D.A.; Halfman, B.; Jensen, B.; Brietenbach, F.; Behnken, L.; Willbur, J.; Undersander, D.; Blonde, G.; Lamb, J.F.S. Evaluating Headline fungicide on alfalfa production and sensitivity of pathogens to pyraclostrobin. Plant Health Prog. 2013. [CrossRef]

47. Andrieu, J.; Demarquilly, C.; Sauvant, D. Tables dela valeur nutritive des aliments. In Alimentation Desbovins, Ovins et Caprins; Jarrige, R., Ed.; Inra: Paris, France, 1988; pp. 356-443.

48. Marita, J.M.; Ralph, J.; Hatfield, R.D.; Guo, D.; Chen, F.; Dixon, R.A. Structural and compositional modifications in lignin of transgenic alfalfa down-regulated in caffeic acid 3-O-methyl-transferase and caffeoyl coenzyme A 3-O-methyltransferase. Phytochemistry 2003, 62, 53-65. [CrossRef] 
49. Bouton, J.H. Breeding lucerne for persistence. Crop Pasture Sci. 2012, 63, 95-106. [CrossRef]

50. Putnam, D.; Orloff, S.; Ackerly, T. Agronomic practices and forage quality. In Proceedings of the 2000 National Alfalfa Symposium, Las Vegas, NV, USA, 10-12 December 2000; University of CA Cooperative Extension: Davis, CA, USA, 2000.

51. Hanks, R.J.; Keller, J.; Rasmussen, V.P.; Wilson, G.D. Line source sprinkler for continuous variable irrigation-crop production studies. Soil Sci. Soc. Am. Proc. 1976, 40, 426-429. [CrossRef]

52. Djaman, K.; O’Neill, M.; Owen, C.K.; Smeal, D.; Koudahe, K.; West, M.; Allen, S.; Lombard, K.; Irmak, S. Crop Evapotranspiration, Irrigation Water Requirement and Water Productivity of Maize from Meteorological Data under Semiarid Climate. Water 2018, 10, 405. [CrossRef]

53. Lengkeek, V.H. Field and cereal crop disease reports: Alfalfa. Fungic. Nematic. Tests 1980, 36, 83.

54. Matheron, M.E.; Matejka, J.C. Cereal and forage reports: Alfalfa. Fungic. Nematic. Tests 1988, 45, 168.

55. Schmiedeknecht, M. Environmental tolerance range of Meliolales as mirrored in their horizontal and vertical distribution patterns. Microbiol. Res. 1995, 150, 271-280. [CrossRef]

56. Venier, L.A.; Hopkin, A.A.; McKenney, D.W.; Wang, Y. A spatial, climate-deterimined risk rating for Scleroderris disease of pines of Ontario. Can. J. For. Res. 1998, 28, 1398-1404. [CrossRef]

57. Talley, S.M.; Coley, P.D.; Kursar, T.A. The effects of weather on fungal abundance and richness among 25 communities in the Intermountain West. BMC Ecol. 2002, 2, 7. [CrossRef] [PubMed]

58. Makowski, D.; Bancal, R.; Vicent, A. Estimation of wetness duration requirements of foliar fungal pathogens with uncertain data-An application to Mycosphaerella nawae. Phytopathology 2011, 11, 1346-1354. [CrossRef] [PubMed]

59. Yang, H.; An, F.; Yang, F.; Wang, Z. The impact of irrigation on yield of alfalfa and soil chemical properties of saline-sodic soils. PeerJ 2019, 7, e7148. [CrossRef] [PubMed]

60. Sammis, T. Yield of alfalfa and cotton as influenced by irrigation. Agron. J. 1981, 73, 323-329. [CrossRef]

61. Montazar, A.; Sadeghi, M. Effects of applied water and sprinkler irrigation uniformity on alfalfa growth and hay yield. Agric. Water Manag. 2008, 95, 1279-1287. [CrossRef]

62. Klocke, N.L.; Currie, R.S.; Holman, J.D. Alfalfa Response to Irrigation from Limited Water Supplies. Trans. ASABE 2013, 56, 1759-1768. [CrossRef]

63. Lamm, F.R.; Harmoney, K.R.; Aboukheira, A.A.; Johnson, S.K. Alfalfa production with subsurface drip irrigation in the central great plains. Trans. ASABE 2012, 55, 1203-1212. [CrossRef]

64. Djaman, K.; Irmak, S. Soil water extraction patterns and crop, irrigation, and evapotranspiration water use efficiency of maize under full and limited irrigation and rainfed settings. Trans. ASABE 2012, 55, 1223-1238. [CrossRef]

(C) 2020 by the authors. Licensee MDPI, Basel, Switzerland. This article is an open access article distributed under the terms and conditions of the Creative Commons Attribution (CC BY) license (http://creativecommons.org/licenses/by/4.0/). 